\title{
IODINE CATALYZED CASCADE SYNTHESIS OF FLAVONE DERIVATIVES FROM 2'-ALLYLOXY- $\alpha$, B-DIBROMOCHALCONES
}

\author{
BEENA R. NAWGHARE, SUNIL V. GAIKWAD, ABDUL RAHEEM AND PRADEEP D. LOKHANDE*
}

The Centre for Advanced Studies, Department of Chemistry, University of Pune, Pune 411007 India.

(Received: January 30, 2013 - Accepted: October 2, 2013)

\begin{abstract}
Synthesis of flavones from 2'-allyloxy- $\alpha, \beta$-dibromochalcones has been described. The iodine induced oxidative cyclization of 2 '-allyloxy- $\alpha$, $\beta$-dibromochalcones results into the formation of 3-bromoflavanones which ultimately gives flavones. Dehydrobromination of 3-bromoflavanone to give flavone is the preferred reaction over dehydrogenation.
\end{abstract}

Key words: Flavones, cyclization, oxidation, dehydrobromination, iodine, dimethyl sulfoxide

\section{INTRODUCTION}

Flavones are mainly found in wide variety of natural sources ${ }^{1}$ and known to posses many biological activities such as free radical scavengers, ${ }^{2}$ anti-HIV ${ }^{3}$ and anticancer agent. ${ }^{4}$ Glycosides isolated from the whole plant of Anaphalis aureo-punctata, Chrysanthemum morifolium shows antitumor, antibacterial, antifungal, antiviral, antispirochetal and anti-inflammatory activities. ${ }^{6}$ 3-Bromoflavones are used in drugs and for synthesis of alkylated and arylated flavones. It is observed that variety of chalcones, flavones and flavanones with bromo substituent exhibits anti-tuberculosis activity. 6-Bromoflavone has shown binding affinity to central benzodiazepine receptors and anxiolytic effect in mice. ${ }^{8}$ 3-Haloflavones are used in the synthesis of biflavonoids. ${ }^{9}$ Debromination of 1,2-bis(bromomethyl)arenes by using tetrakis(dimethylamino)ethylene (TDAE) in the presence of olefins and catalytic amount of iodine has been reported. ${ }^{10}$

As an extension of previous studies ${ }^{11}$ we have been interested in the synthesis of 2'-allyloxy- $\alpha, \beta$-dibromochalcones, which leads to the corresponding 3-bromoflavones by using iodine in dimethylsulfoxide reagent. In earlier work 2'-allyloxy chalcones when reacted with DMSO-I reagent, allyl group was smoothly removed followed by cyclization and dehydrogenation to give flavones. We envised that $\alpha, \beta$-dibromochalcones expected to eliminate $\mathrm{HBr}$ and then dehydrogenation to give 3-bromoflavones. Same study is reported in present work.

\section{EXPERIMENTAL}

TLC was performed on E-Merck precoated $60 \mathrm{~F}_{254}$ plates and the spots were rendered visible by exposing to UV light and iodine. Melting points were determined with an Electro thermal model 9100 apparatus and are uncorrected. IR spectra were recorded on a Shimadzu 8000 spectrophotometer. The ${ }^{1} \mathrm{H}$ and ${ }^{13} \mathrm{C}$ NMR spectra were recorded on Varian spectrometer. Chemical shifts $(\delta)$ are reported in ppm and with reference to tetramethyl silane as internal standard. Mass spectra (GCMS) were recorded on a Shimadzu Q 5050 spectrometer.

Typical procedure for the synthesis of flavones (2a-t): To a solution of 2'-allyloxy- $\alpha, \beta$-dibromochalcones $(1 \mathrm{mmol})$ in DMSO $(5 \mathrm{~mL})$ was added iodine $(1 \mathrm{mmol})$ and the reaction mixture was heated in an oil bath at $130^{\circ} \mathrm{C}$ for $30 \mathrm{~min}$. After cooling, iodine was removed by washing with a saturated solution of sodium thiosulphate and water. The product was then extracted with ethyl acetate and purified by column chromatography (hexane/ethyl acetate, 9:1).

\section{Spectral data}

6,8-Dichloro-2-phenyl-4H-chromene-4-one (Table, 2i)

White solid; M.p. $160-161{ }^{\circ} \mathrm{C},{ }^{1} \mathrm{H}-\mathrm{NMR}\left(\mathrm{CDCl}_{3} 300 \mathrm{MHz}\right) \delta 8.10(\mathrm{~d}, 1 \mathrm{H}$, $\mathrm{J}=2.3 \mathrm{~Hz}, \mathrm{Ar}-\mathrm{H}), 7.99(\mathrm{dd}, 2 \mathrm{H}, \mathrm{J}=1.4,7.4 \mathrm{~Hz}, \mathrm{Ar}-\mathrm{H}), 7.74(\mathrm{~d}, 1 \mathrm{H}, \mathrm{J}=2.7 \mathrm{~Hz}, \mathrm{Ar}-$ $\mathrm{H})$, 7.58-7.54 (m, 3H, Ar-H), $6.86(\mathrm{~S}, 1 \mathrm{H},=\mathrm{CH}) ;{ }^{13} \mathrm{C}-\mathrm{NMR}\left(\mathrm{CDCl}_{3}\right) \delta 176.2$, 163.2, 133.6, 132.1, 130.7, 130.6, 129.1, 126.2, 125.5, 124.3, 123.7, 106.9; IR $\left(\mathrm{KBr} / \mathrm{cm}^{-1}\right): 3390,3065,2914,1725,1662,1602,1567,1451 ; \mathrm{MS}(\mathrm{m} / \mathrm{z}): 290$ (M+ ion); Anal. calcd for $\mathrm{C}_{15} \mathrm{H}_{8} \mathrm{Cl}_{2} \mathrm{O}_{2}: \mathrm{C}, 61.88 ; \mathrm{H}, 2.67 \%$ Found: $\mathrm{C}, 61.47$; $\mathrm{H}, 2.91 \%$

\section{Result and discussion}

2'-allyloxy chalcones were prepared by reacting 2'-hydroxy chalcones with allyl bromide in presence of potassium carbonate and dimethylsulphoxide at $\mathrm{rt}$ for $24 \mathrm{~h}$. Bromination of 2'-allyloxy chalcones by bromine water in presence of acetic acid resulted into formation of 2'-allyloxy- $\alpha, \beta$-dibromochalcones (1) at $\mathrm{rt}$ in $24 \mathrm{~h}$.

2 '-allyloxy- $\alpha, \beta$-dibromochalcones (1) when reacted with iodine (1 mmol) in presence of dimethylsulfoxide, it was expected to follow the steps deallylation, cyclization, debromination and dehydrogenation to give 3 -bromoflavones $(\mathbf{5})$. But it is surprise to see that under given condition 2 '-allyloxy- $\alpha, \beta$-dibromochalcones (1) converted to flavones (2) with high yield (Scheme 1).<smiles></smiles>

Scheme 1

From the above results it is seen that flavones (2) could be formed from 2 '-allyloxy- $\alpha, \beta$-dibromochalcones (1) with the intermediate 3-bromoflavanones (4) which have undergone dehydrobromination in DMSO- $\mathrm{I}_{2}$ reagent (Scheme 2).

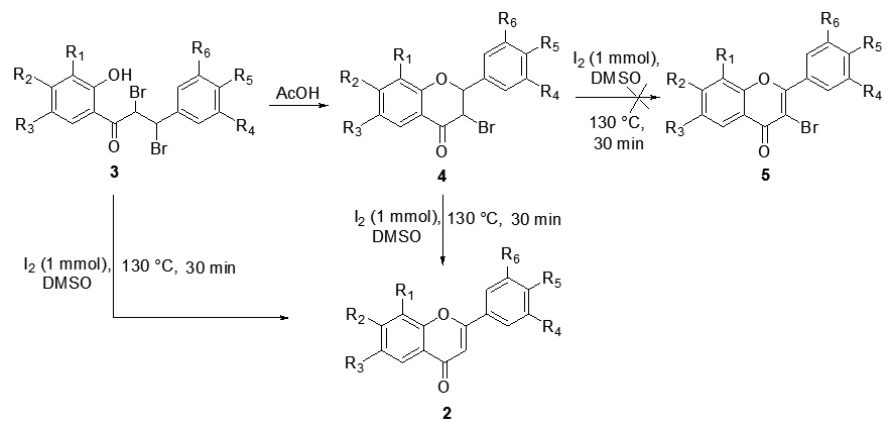

Scheme 2

In reported method 2-iodoxybenzoic acid (IBX) selectively oxidize substituted flavanones to flavones. ${ }^{12}$ Synthesis of Bromo-substituted flavonelike troponoid compounds by oxidative cyclization of 3-cinnamoyl-5,7dibromotropolones was reported by using DMSO/ $/ 2 / \mathrm{H}_{2} \mathrm{SO}_{4}$ system. ${ }^{13}$ Earlier, we have reported the use of DMSO- $\mathrm{I}_{2}$ reagent for deallylation, ${ }^{14 a, b}$ oxidation of flavanones to flavones ${ }^{14 \mathrm{c}}$ and dihydrochalcones to chalcones. ${ }^{14 \mathrm{~d}}$

In present methodology, to verify whether deallylation of 2 '-allyloxy- $\alpha$, $\beta$-dibromochalcones (1) is the first reaction followed by cyclization and then 
debromination, 2'-hydroxy- $\alpha, \beta$-dibromochalcones (3) were prepared. These chalcones $(3)$ when reacted with iodine $(1 \mathrm{mmol})$ in dimethylsulfoxide at 130 ${ }^{\circ} \mathrm{C}$, it resulted in the formation of flavones (2) (Scheme 2). Here it was thought that 2'-hydroxy dibromochalcones could have undergone debromination first to give 2'-hydroxy chalcones which in turn converted to flavones. But flavone formation in this reaction was unable to clear whether debromination takes place first or dehydrogenation. Then 2'-hydroxy- $\alpha, \beta$-dibromochalcones (3) prepared from 2'-hydroxy chalcones treated with acetic acid. The product was 3-bromoflavanones (4) which undergone dehydrobromination with DMSO$\mathrm{I}_{2}$ to give flavones (2) (Scheme 2). Under this condition 3-bromoflavone was not formed. This indicates dehydrobromination of 3-bromoflavone is preferred over dehydrogenation. The other possible sequence of reaction could be debromination of 2'-allyloxy- $\alpha, \beta$-dibromochalcones (1), followed by deallylation, cyclization and oxidation. To study these reactions, $\alpha$, $\beta$-dibromochalcones (6) were reacted with iodine in dimethylsulfoxide reagent (Scheme 3). It has undergone debromination at $130^{\circ} \mathrm{C}$ resulting in the formation of chalcones (7). But again this study cannot confirm that deallylation of 2 '-allyloxy chalcones is preferred over debromination. Under present condition it is still difficult to analyze whether deallylation is a preferred reaction over debromination or vice versa in presence of DMSO- $\mathrm{I}_{2}$ reagent. Therefore we are unable to suggest exact sequence of the reaction. But from the above study it is confirm that DMSO- I reagent is useful for deallylation, cyclization, debromination and dehydrobromination of 2'-allyloxy- $\alpha, \beta$-dibromochalcones (1) which can yield flavones. By using this cascade synthesis, various flavones were synthesized from substituted 2'-allyloxy- $\alpha, \beta$-dibromochalcones (1) (Table ). It is noteworthy that the flavone (2t) is naturally occurring compound. ${ }^{15}$<smiles>[R]c1cc([R])cc(C(=O)C(Br)C(Br)c2ccc([R])c([R])c2)c1</smiles>

Scheme 3

2'-allyloxy- $\alpha, \beta$-dibromochalcones (1) when reacted with iodine in dimethylsulfoxide, it is assumed that deallylation results in the formation of oxyanion. In next step cyclization facilitates debromination and gives 3-bromoflavanone (5). Finally, dehydrobromination of 3-bromoflavanone (5) influenced by iodide ion yield flavone (2). However no mechanistic study has been done, this mechanism is proposed on the basis of earlier observations.

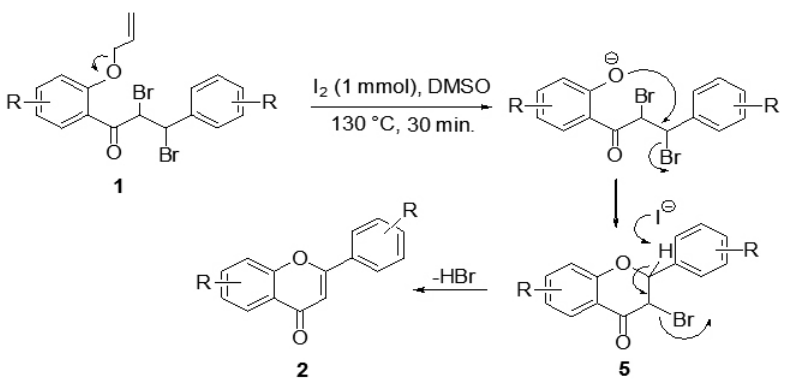

Scheme 4

Thus cascade reaction supports for the reduction in the number of steps as well as time in ending the synthesis to the target molecule. ${ }^{16}$

Table Physicochemical data of flavones.

\begin{tabular}{|c|c|c|c|c|c|c|c|c|c|}
\hline Entry & $\mathbf{R}_{1}$ & $\mathbf{R}_{2}$ & $\mathbf{R}_{3}$ & $\mathbf{R}_{4}$ & $\mathbf{R}_{5}$ & $\mathbf{R}_{6}$ & Product (2) & $\mathrm{Mp}\left({ }^{\circ} \mathrm{C}\right)$ & Yield (\%) \\
\hline 1 & $\mathrm{Cl}$ & $\mathrm{H}$ & $\mathrm{H}$ & $\mathrm{OCH}_{3}$ & $\mathrm{OCH}_{3}$ & $\mathrm{H}$ & $2 a$ & 145 & 98 \\
\hline 2 & $\mathrm{H}$ & $\mathrm{H}$ & $\mathrm{CH}_{3}$ & $\mathrm{H}$ & $\mathrm{H}$ & $\mathrm{H}$ & $2 \mathbf{b}$ & $117-119$ & 90 \\
\hline 3 & $\mathrm{Cl}$ & $\mathrm{H}$ & $\mathrm{H}$ & $\mathrm{H}$ & $\mathrm{OCH}_{3}$ & $\mathrm{H}$ & $2 c$ & 130 & 80 \\
\hline 4 & $\mathrm{H}$ & $\mathrm{H}$ & $\mathrm{H}$ & $\mathrm{OCH}_{3}$ & $\mathrm{OCH}_{3}$ & $\mathrm{H}$ & $2 d$ & 178-179 & 78 \\
\hline 5 & $\mathrm{H}$ & $\mathrm{OCH}_{2} \mathrm{Ph}$ & $\mathrm{H}$ & $\mathrm{H}$ & $\mathrm{H}$ & $\mathrm{H}$ & $2 \mathrm{e}$ & 150 & 80 \\
\hline 6 & $\mathrm{H}$ & $\mathrm{H}$ & $\mathrm{CH}_{3}$ & $\mathrm{H}$ & $\mathrm{OCH}_{3}$ & $\mathrm{H}$ & $2 f$ & 168 & 79 \\
\hline 7 & $\mathrm{H}$ & $\mathrm{H}$ & $\mathrm{Cl}$ & $\mathrm{H}$ & $\mathrm{OCH}_{3}$ & $\mathrm{H}$ & $2 \mathrm{~g}$ & 178 & 90 \\
\hline 8 & $\mathrm{H}$ & $\mathrm{OCH}_{2} \mathrm{Ph}$ & $\mathrm{H}$ & $\mathrm{OCH}_{3}$ & $\mathrm{H}$ & $\mathrm{H}$ & $2 \mathrm{~h}$ & 180 & 75 \\
\hline 9 & $\mathrm{Cl}$ & $\mathrm{H}$ & $\mathrm{Cl}$ & $\mathrm{H}$ & $\mathrm{H}$ & $\mathrm{H}$ & $2 \mathrm{i}$ & $160-161$ & 90 \\
\hline 10 & $\mathrm{H}$ & $\mathrm{H}$ & $\mathrm{H}$ & $\mathrm{H}$ & $\mathrm{H}$ & $\mathrm{H}$ & $2 j$ & $95-96$ & 91 \\
\hline 11 & $\mathrm{H}$ & $\mathrm{H}$ & $\mathrm{Cl}$ & $\mathrm{H}$ & $\mathrm{H}$ & $\mathrm{H}$ & $2 \mathrm{k}$ & 183-184 & 90 \\
\hline 12 & $\mathrm{Cl}$ & $\mathrm{H}$ & $\mathrm{Cl}$ & $\mathrm{H}$ & $\mathrm{H}$ & $\mathrm{H}$ & 21 & 180-184 & 95 \\
\hline 13 & $\mathrm{H}$ & $\mathrm{H}$ & $\mathrm{CH}_{3}$ & $\mathrm{OCH}_{3}$ & $\mathrm{OCH}_{3}$ & $\mathrm{H}$ & $2 m$ & 189 & 91 \\
\hline 14 & $\mathrm{H}$ & $\mathrm{H}$ & $\mathrm{H}$ & $\mathrm{Cl}$ & $\mathrm{H}$ & $\mathrm{H}$ & $2 n$ & $251-252$ & 89 \\
\hline 15 & $\mathrm{Cl}$ & $\mathrm{H}$ & $\mathrm{Cl}$ & $\mathrm{H}$ & $\mathrm{Cl}$ & $\mathrm{H}$ & 20 & $217-219$ & 94 \\
\hline 16 & $\mathrm{Cl}$ & $\mathrm{H}$ & $\mathrm{Cl}$ & $\mathrm{OCH}_{3}$ & $\mathrm{OCH}_{3}$ & $\mathrm{H}$ & $2 p$ & 144-146 & 98 \\
\hline 17 & $\mathrm{H}$ & $\mathrm{H}$ & $\mathrm{H}$ & $\mathrm{H}$ & $\mathrm{Br}$ & $\mathrm{H}$ & $2 q$ & 178 & 92 \\
\hline 18 & $\mathrm{H}$ & $\mathrm{OCH}_{2} \mathrm{Ph}$ & $\mathrm{H}$ & $\mathrm{H}$ & $\mathrm{OH}$ & $\mathrm{OCH}_{3}$ & $2 r$ & 180 & 84 \\
\hline 19 & $\mathrm{H}$ & $\mathrm{OCH}_{2} \mathrm{Ph}$ & $\mathrm{H}$ & $\mathrm{OCH}_{3}$ & $\mathrm{OCH}_{3}$ & $\mathrm{OH}$ & $2 s$ & 180 & 83 \\
\hline 20 & $\mathrm{H}$ & $\mathrm{OH}$ & $\mathrm{H}$ & $\mathrm{H}$ & $\mathrm{OCH}_{3}$ & $\mathrm{OH}$ & $2 t$ & 180 & 88 \\
\hline
\end{tabular}

${ }^{a}$ Isolated yields of the products. ${ }^{\mathrm{b}}$ Products are characterized by spectral analysis.

\section{CONCLUSION}

We have reported cascade synthesis of flavones (2) from 2'-allyloxy- $\alpha$, $\beta$-dibromochalcones (1) using iodine in dimethylsulfoxide. Deallylation, cyclization, debromination and dehydrobromination reaction occur in one step. Dehydrobromination of 3-bromoflavanone to give flavone is the preferred reaction over dehydrogenation. 


\section{REFERENCES}

1. (a) J. B. Harborne, C. A. Williams, Nat. Prod. Rep. 18, 310 (2001). (b) V. M. Malikov, M. P. Yuldashev, Chem. Nat. Compd. 38, 358 (2002). (c) T. Nagao, F. Abe, J. Kinjo, H. Okabe, Biol. Pharm. Bull. 7, 875 (2002).

2. A. T. Dinkova-Kostova, C. Abeygunawardana, P. J. Talaey, Med. Chem. 41, 5278 (1998).

3. A. Mantas, E. Deretey, F. H. Ferretti, M. R. Estrada, I. G. Csizmadia, Theochem. 504, 171 (2000).

4. C. Han, Cancer Lett. 114, 153 (1997).

5. Y. Li, Y. Q. Wu, S. Li, Chinese Chemical Letters, 14(1), 66 (2003).

6. (a) J. Zhang, A. W. Ding, Y. B. Li, D. W. Qian, J. A. Duan, Z. Q. Yin, Chinese Chemical Letters, 17(8), 1051 (2006). (b) Jiangsu New Medical College, The Dictionary of Traditional Chinese Medicine. Shanghai: Shanghai Science and Technology Press, 2008 (1997).

7. M. T. Flavin, Y. M. Lin, Y. Zhou, L. M. Zhou, W. Nie, F. C. Chen, Bioorganic and Medicinal Chemistry, 10, 2795 (2002).

8. M. Marder, H. Viola, C. Wasowski, C. Wolfman, G. Peter, Waterman, K. Bruce, Cassels, H. Jorge, Medina, C. Alejandro, Paladini, Biochemical and Biophysical Research Communications, 903, 384 (1996).

9. L. L. Yu, F. J. Zhang, Synth. Commun. 23(8), 1075 (1993).
10. N. Sonoda, Y. Nishiyama, H. Kawabata, A. Kobayashi, T. Nishino, Tetrahedron Lett., 46, 867 (2005).

11. (a) P. D. Lokhande, S. S. Sakate, K. N. Taksande, B. R. Nawghare, Tetrahedron Lett. 46(9), 1573 (2005). (b) P. D. Lokhande, B. R. Nawghare, S. S. Sakate, Journal of Heterocyclic Chem. DOI: 10.1002/jhet.1580 (2011).

12. R. Bernini, M. Barontini, F. Crisante, G. Fabrizi, Tetrahedron 66, 6047 (2010).

13. W. Gao, Y. Li, M. Chang, M. Sun, W. Li, Chinese Journal of Chemistry, 27(10), 2073 (2009).

14. (a) P. D. Lokhande, B. R. Nawghare, Indian J. Chem. 51B(01), 328 (2012). (b) P. D. Lokhande, B. R. Nawghare Synthetic Communications, 43(14), 1955 (2013). (c) P. D. Lokhande, B. R. Nawghare, S. G. Funde, A. Raheem, Chin. J. Chem. 30, 1695 (2012). (d) P. D. Lokhande, B. R. Nawghare Synthetic Communications, DOI: 10.1080/00397911.2012.667490 (2012).

15. (a) M. G. Nair, D. H. S. Silva, Y. Zhang, L. A. Santos, V. S. J. Bolzani, Agric. Food Chem. 55, 2569 (2007).

16. (a) Z. Du, H. Ng, K. Zhang, H. Zeng, J. Wang, Organic \& Biomolecular Chemistry, 9(20), 6930 (2011). (b) M. Xia, G. F. Xiang, B. Wu, Y. F. Han, Advanced Synthesis \& Catalysis 350(6), 817 (2008). (c) C. H. Ko, S. C. Shen, Y. C. Chen, Free Radical Biology \& Medicine 36(7), 897 (2004). 